\title{
Prevalence and predictors of under- nutrition among school children in a rural South-eastern Nigerian community: a cross sectional study
}

Rufina N. B. Ayogu*, Ifeoma C. Afiaenyi, Edith U. Madukwe and Elizabeth A. Udenta

\begin{abstract}
Background: School children in developing countries like Nigeria are faced with numerous nutrition and health problems. Lack of functional school health and nutrition programmes in Enugu state, Nigeria may be associated with dearth of data on associated factors. Identifying these factors could inform the design and implementation of school-based programmes aimed at ameliorating these problems.

Methods: A cross sectional survey involving 450 primary and secondary school children aged 6-15 years was conducted in Ede-Oballa, a rural community in Enugu state, South-eastern Nigeria. Selection of the pupils was by multistage sampling technique. Data were collected through interviewer administered questionnaire, anthropometric measurements of weight and height, 3-day weighed food intake, stool microscopy and blood analyses for malaria, zinc and vitamin A. Bivariate and multivariate logistic regression analyses were used to evaluate associations of interest with significance accepted at $P<0.05$.

Results: The school children were affected by underweight (18.2\%), stunting (41.6\%), thinness (20.0\%), zinc (43.3\%) and vitamin A (51.1\%) deficiencies. After adjusting for potential confounders, weekly food expenditure was a major predictor of under-weight ( $A O R=0.19,95 \% \mathrm{Cl}: 0.08,0.46)$, stunting $(A O R=0.36,95 \% \mathrm{Cl}: 0.13,0.95)$ and thinness $(A O R=0.49,95 \% \mathrm{Cl}$ : $0.30,0.80$ ); household income was also a predictor of thinness (AOR $=0.47,95 \% \mathrm{Cl}: 0.25,0.88$ ). Males had lower odds of being stunted than females ( $A O R=0.31,95 \% \mathrm{Cl}: 0.11,0.83$ ). The odd of being underweight was higher in female headed households than in households headed by males ( $A O R=0.30,95 \% \mathrm{Cl}: 0.12,0.75)$. Tapeworm was an independent predictor of vitamin $\mathrm{A}(\mathrm{AOR}=3.59 ; 95 \% \mathrm{Cl}: 1.06,12.13)$ and zinc $(\mathrm{AOR}=3.64 ; 95 \% \mathrm{Cl}: 1.02,12.98)$ deficiencies. Children with whipworm were more likely to be zinc ( $\mathrm{AOR}=3.80 ; 95 \% \mathrm{Cl}: 1.11,13.04)$ and vitamin $\mathrm{A}(\mathrm{AOR}=3.79 ; 95 \% \mathrm{Cl}: 1.12$, 12.89) deficient than those uninfected.

Conclusion: Underweight, stunting, thinness, vitamin A and zinc deficiency among the school children were functions of weekly food expenditure, gender of household head and household income, tapeworm, whipworm, and sex. These findings emphasize the need for effective school- and community-based interventions.
\end{abstract}

Keywords: Stunting, Underweight, Thinness, Vitamin A deficiency, Zinc deficiency, Rural, School children, Determinants, Nigeria

\footnotetext{
* Correspondence: rufina.ayogu@unn.edu.ng

Department of Nutrition and Dietetics, University of Nigeria, Nsukka, Nsukka,

Nigeria
}

(c) The Author(s). 2018 Open Access This article is distributed under the terms of the Creative Commons Attribution 4.0 International License (http://creativecommons.org/licenses/by/4.0/), which permits unrestricted use, distribution, and reproduction in any medium, provided you give appropriate credit to the original author(s) and the source, provide a link to the Creative Commons license, and indicate if changes were made. The Creative Commons Public Domain Dedication waiver (http://creativecommons.org/publicdomain/zero/1.0/) applies to the data made available in this article, unless otherwise stated. 


\section{Background}

Under-nutrition is a serious public health problem among children with huge consequences on the affected individuals, their families and the nation. Deficiencies of micronutrients such as iron, zinc and vitamin A affect a third to half of the world population [1] especially women, infants, and children in resource - poor households in low and medium income countries like Nigeria. Anthropometric deficits and micronutrient deficiencies have been shown [2-11] to be problems of public health significance among school children in different parts of Nigeria. A study conducted by Oninla, Owa, Onayade and Taiwo [2] on the nutritional status of children attending urban and rural public primary schools in Ife Central Local Government Area of Oyo State, Nigeria showed that children in both rural and urban areas were affected by anthropometric deficits with the rural school children being more disadvantaged. These nutrition problems are important constraints to effective child growth and development and compromise the school child's ability to benefit maximally from his education. Poor nutrition and health among school children have been reported to contribute to the general inefficiency of education systems worldwide and improved nutrition and health lead to better performances, fewer repeated classes and reduced dropout rates [12]. School-aged children who suffered severe clinical under-nutrition in early childhood usually have poor cognition, school achievement, and motor skills, and have behaviour problems compared with matched controls [13].

Not much is being done to ensure good health and nutritional status of the school-aged child, particularly in the study area. This probably is a consequence of dearth of data on the factors associated with under-nutrition among school children. The school-aged child who is a survivor in an environment of high under-five morbidity and mortality is often not regarded as vulnerable and therefore not targeted for many nutrition and health programmes. Absence of functional school health programme further increases the vulnerability of these children to various nutrition and health problems that jeopardize their health and educational potentials.

Multiple factors may be responsible for the various forms of under-nutrition that affect Nigerian school children. Inadequate nutrient intake, infections (especially febrile and parasitic infections), and various socio-economic and environmental variables often lead to nutrition problems in children. Establishment of these factors is a major way of enhancing planning and implementation of interventions to curb the menace of these problems.

Although some studies on nutritional status of school children have been conducted in different parts of Nigeria, few have investigated the contributory factors of undernutrition among school children and none to the best of our knowledge has been conducted in Enugu state. Enugu state is one of the states in which the Federal Government of Nigeria intended to commence school feeding. The data from this study would therefore inform policy makers on relevant factors to consider while planning school meal programme in the state and Nigeria as a whole. It was in this light that this study was undertaken to assess the prevalence of underweight, stunting, thinness, vitamin A and zinc deficiencies among rural school children aged 615 years in a South-eastern Nigerian community - EdeOballa and determine the factors associated with them.

\section{Methods \\ Study design}

The study employed a cross sectional survey design to determine the prevalence and predictors of under-nutrition among school children in Ede-Oballa.

\section{Study setting}

Ede-Oballa is a typical rural community in South-eastern Nigeria made up of two large autonomous communities (Ede-Ukwu and Ede-Enu). It is located south of Nsukka town, the head quarters of Nsukka LGA of Enugu state. It had seven primary and three secondary schools, each densely populated. These were both state and private schools.

\section{Participants}

The study comprised all free living (apparently healthy) primary and secondary school children aged 6-15 years in all ten schools in the study area. The study excluded sick children and those whose parents denied consent.

\section{Sample size and sampling technique}

Sample size was derived from a single population proportion formula $\left(4 \mathrm{P}(1-\mathrm{P}) / \mathrm{W}^{2}\right)$. We used vitamin $\mathrm{A}$ deficiency prevalence of $49.8 \%$ at $95 \%$ confidence interval and added $0.5 \%$ non response rate. The figure obtained was rounded off to 450 to reduce sampling error. The respondents were selected using multistage sampling technique: (a) identification of school children of 6-15 years in all the schools using school registers; (b) determination of the sample size per school and class by proportionate stratified sampling (with respect to age and sex); this was to ensure a wider representation and (c) the respondents were selected from each strata per school by simple random sampling technique. A subsample of 90 (20\%) was randomly selected for weighed food intake and biochemical tests.

\section{Data collection methods Questionnaire}

General characteristics of the school children were elicited by the use of a validated and pretested questionnaire which was interviewer administered to each parent-child pair. 


\section{Anthropometry}

A Harson's bathroom salter scale (120 Kg capacity) was used in weight measurement. The scale was constantly maintained at zero prior to weighing each child. Each child was made to stand on the platform of the scale without shoes, hands by the sides and head held erect. Minimal clothing was allowed and reading was taken to the nearest $0.1 \mathrm{~kg}$. Microtoise height metre rule was used to obtain the heights of the children. The children were made to stand erect without foot wears; with feet parallel, heels together, arms hanging by the sides and the buttocks, shoulder and back of the head touching the metre rule, the head piece was lowered gently to come in direct contact with the head. Readings were taken to the nearest $0.1 \mathrm{~cm}$. Body mass index was calculated as the relationship of weight in $\mathrm{kg}$ to height in metres squared. Weight, height and BMI values were related to age and compared with WHO [14] child growth standards for weight-for-age, height-for-age and BMI-for-age z-scores. Children were classified as underweight, stunted and thin if z-scores for weight-for-age, height-for-age and BMI-for-age were less than or equal to -2SD below the WHO median of standards for age and sex. Overweight and obesity were taken as z-scores of $+2 \mathrm{SD}$ and $+3 \mathrm{SD}$, respectively.

\section{Dietary assessment}

Dietary assessment was carried out by a 3-day weighed food intake ( 2 weekdays and one weekend day) to determine energy, carbohydrate, and vitamin A and zinc intakes of 90 school children. All raw ingredients including the cook pot were weighed with kitchen scales prior to cooking and their values recorded. After cooking, the pot containing the food was weighed and the weight of the empty pot subtracted from it to obtain the weight of the cooked food. The quantity consumed by each child was obtained by subtracting plate wastes and leftovers from the portion given to the child. Snacks and foods bought and eaten outside the homes were estimated using household measures and the values recorded. Nutrients in the foods were calculated with the aid of food composition tables. The mean nutrient intake of the 3 days was related to recommended nutrient intakes (RNI) for these nutrients to obtain the percentage contributions. Adequate intake was taken as values equal to or above the RNI [15]. Data were not collected on feast/festival days as food intakes on these days may not reflect the usual food intake of the children.

\section{Biochemical analyses}

Serum vitamin A was assayed by High Performance Liquid Chromatography and deficiency was defined as serum retinol level of $\leq 20 \mu \mathrm{g} / \mathrm{dl}$ [16]. Serum zinc was determined by Atomic Absorption Spectrophotometry (AAS). Deficiency was defined as values less than $80 \mu \mathrm{g} / \mathrm{dl}$ [16]. Thin blood film method was used to test for malaria parasites in the erythrocytes of fresh whole blood. The wet mount direct method was used to analyze fresh stool for intestinal parasites.

\section{Statistical analysis}

Data were analyzed using the Statistical Package for Social Sciences (SPSS) for windows version 16.0. Descriptive statistics was used for general characteristics of the children and the results were presented in frequencies and percentages. Bivariate analysis (with Chi-square test) was employed to identify association between each of the independent variables and the response variables. Since chi-square analysis does not take into consideration confounding effects; we used multivariate logistic regression analysis (with stepwise backward elimination procedure) to adjust for simultaneous effects of multiple factors and to control the effects of confounding variables on the response variable. Odds ratios with 95\% confidence interval were generated from this and used to determine the independent strength of the associations. $P<0.05$ was considered significant.

\section{Results}

\section{General characteristics of the respondents}

The response rate observed in this study was $100 \%$. Majority (63.1\%) of the children had mothers who were aged 35 years and above. More than half of the mothers (67.3\%) had less than secondary education. Majority were married (93.3\%) and employed (89.6\%). Few came from polygamous $(20.2 \%)$ and single parent $(18.0 \%)$ families. Female household heads constituted $45.3 \%$ while $70.0 \%$ had household monthly income of 25,000 Naira (79.43 US Dollar) and below. About 45\% spent 5000 Naira (15.89 US Dollar) and below on food weekly. Energy, carbohydrate and vitamin A intakes were inadequate providing less than $100 \%$ of the RNI for $67.8 \%, 16.7 \%$ and $26.7 \%$ of the children, respectively. Zinc intake was adequate for all the children. Intakes were mainly plant based (Table 1).

\section{Prevalence of under-nutrition among the school children} Underweight was found among $18.2 \%$ of the school children; $20.0 \%$ of them were thin and $41.6 \%$ were stunted. Only $9.3 \%$ were overweight and no (0\%) child was obese. Zinc deficiency affected $43.3 \%$ and $51.1 \%$ were vitamin A deficient. School children who were aged 6-9 years had the highest (56.2\%) prevalence of vitamin A deficiency while the highest prevalence of stunting (45.9\%) and thinness $(28.6 \%)$ was found among the $13-15$ year olds. The 10-12 year olds had the highest prevalence of underweight (31.1\%) and zinc deficiency (48.0\%). On chi square analysis, the prevalence of underweight, stunting and thinness increased significantly with age. The relationship was stronger with thinness $(P<0.001)$ and stunting $(P<0.01)$ (Table 2). 
Table 1 General characteristics of the school children $(N=450)$

\begin{tabular}{|c|c|c|c|}
\hline Variables & Frequency & Percentage & $95 \% \mathrm{Cl}$ \\
\hline \multicolumn{4}{|l|}{ Age of the mother } \\
\hline $15-34$ years & 166 & 36.9 & $30.0-51.1$ \\
\hline 35 years and above & 284 & 63.1 & $48.9-70.0$ \\
\hline Total & 450 & 100.0 & \\
\hline \multicolumn{4}{|l|}{ Mother's educational level } \\
\hline Less than secondary education & 303 & 67.3 & $23.3-43.3$ \\
\hline Secondary education and above & 147 & 32.7 & $56.7-76.7$ \\
\hline Total & 450 & 100.0 & \\
\hline \multicolumn{4}{|l|}{ Mother married } \\
\hline Yes & 420 & 93.3 & $11.1-27.8$ \\
\hline No & 30 & 6.7 & $72.2-98.9$ \\
\hline Total & 450 & 100.0 & \\
\hline \multicolumn{4}{|l|}{ Occupation } \\
\hline Employed & 403 & 89.6 & $58.2-97.1$ \\
\hline Unemployed & 47 & 10.4 & $7.6-13.3$ \\
\hline Total & 450 & 100.0 & \\
\hline \multicolumn{4}{|l|}{ Family type } \\
\hline Monogamy & 278 & 61.8 & $57.3-66.2$ \\
\hline Polygamy & 91 & 20.2 & $16.7-23.8$ \\
\hline Single & 81 & 18.0 & $14.7-21.8$ \\
\hline Total & 450 & 100.0 & \\
\hline \multicolumn{4}{|l|}{ Household head } \\
\hline Male & 246 & 54.7 & $50.0-59.1$ \\
\hline Female & 204 & 45.3 & $40.9-50.0$ \\
\hline Total & 450 & 100.0 & \\
\hline \multicolumn{4}{|l|}{ Household income } \\
\hline 25,000 Naira and below ( $\leq 79.43 \$)$ & 315 & 70.0 & $61.8-78.9$ \\
\hline Above 25,000 Naira (> 79.43\$) & 135 & 30.0 & $23.6-36.5$ \\
\hline Total & 450 & 100.0 & \\
\hline \multicolumn{4}{|l|}{ Weekly food expenditure } \\
\hline 5000 Naira and below ( $\leq 15.89 \$)$ & 204 & 45.3 & $41.1-50.4$ \\
\hline Above 5000 Naira (> 15.89\$) & 246 & 54.7 & $46.5-62.5$ \\
\hline Total & 450 & 100.0 & \\
\hline \multicolumn{4}{|l|}{ Energy intake $(N=90)$} \\
\hline Adequate ( $\geq 100 \%$ of RNI) & 29 & 32.2 & $25.8-40.2$ \\
\hline Inadequate $(<100 \%$ of RNI) & 61 & 67.8 & $58.0-72.4$ \\
\hline Total & 90 & 100.0 & \\
\hline \multicolumn{4}{|l|}{ Carbohydrate intake $(N=90)$} \\
\hline Adequate ( $\geq 100 \%$ of RNI) & 75 & 83.3 & $75.6-91.1$ \\
\hline Inadequate $(<100 \%$ of RNI) & 15 & 16.7 & $8.9-24.4$ \\
\hline Total & 90 & 100.0 & \\
\hline \multicolumn{4}{|l|}{ Vitamin A intake $(N=90)$} \\
\hline Adequate ( $\geq 100 \%$ of RNI) & 66 & 73.3 & $64.4-83.3$ \\
\hline
\end{tabular}

Table 1 General characteristics of the school children $(N=450)$ (Continued)

\begin{tabular}{llll}
\hline Variables & Frequency & Percentage & $95 \% \mathrm{Cl}$ \\
\hline Inadequate $(<100 \%$ of RNI $)$ & 24 & 26.7 & $16.7-35.6$ \\
Total & 90 & 100.0 & \\
Zinc intake $(\mathrm{N}=90)$ & & \\
Adequate $(\geq 100 \%$ of RNI) & 90 & 100.0 \\
Inadequate $(<100 \%$ of RNI) & 0 & 0.0 \\
Total & 90 & 100.0 \\
\hline RNI, Recommended nutrient intakes, Cl Confidence interval
\end{tabular}

\section{Predictors of underweight, stunting, thinness, zinc and} vitamin A deficiencies

Results of bivariate analysis of factors associated with underweight, stunting and thinness among the school children were presented in Table 3. Gender of household head (COR $=0.30,95 \% \mathrm{CI}$ : 0.13, 0.70), household income $(\mathrm{COR}=0.31,95 \% \mathrm{CI}: 0.11,0.85)$, weekly food expenditure $(\mathrm{COR}=0.18,95 \% \mathrm{CI}: 0.08,0.40)$ and age of the child $(\mathrm{COR}=2.43,95 \% \mathrm{CI}: 0.98,5.99)$ were significant relative risk factors associated with underweight. Significant risk factors for stunting were household income $(\mathrm{COR}=0.61$, 95\% CI: 0.40, 0.93), weekly food expenditure $(\mathrm{COR}=0.55$, 95\% CI: 0.38, 0.80), sex of the child (COR $=0.68,95 \% \mathrm{CI}$ : 0.47, 0.99), age of the child $(\mathrm{COR}=1.60,95 \% \mathrm{CI}: 1.06,2$. 41), malaria $(\mathrm{COR}=0.34,95 \% \mathrm{CI}: 0.14,0.81)$ and tapeworm $(\mathrm{COR}=0.38$, 95\% CI: 0.15, 0.99). Gender of household head (COR $=0.60,95 \% \mathrm{CI}: 0.37,0.97)$, household income $(\mathrm{COR}=0.36,95 \% \mathrm{CI}: 0.19,0.67)$, weekly food expenditure $(\mathrm{COR}=0.40,95 \% \mathrm{CI}: 0.25,0.64)$, age of the child $(\mathrm{COR}=1.91,95 \% \mathrm{CI}: 1.11,3.28)$, and school level $(\mathrm{COR}=1.60,95 \% \mathrm{CI}: 1.01,2.55)$ were risk factors that had significant associations with thinness.

After controlling for all other independent variables, gender of household head was found to be an independent predictor of underweight $(\mathrm{AOR}=0.30,95 \% \mathrm{CI}$ : 0.12, 0.75). Weekly food expenditure proved a significant determinant of underweight $(\mathrm{AOR}=0.19,95 \% \mathrm{CI}$ : 0.08, 0.46), stunting $(\mathrm{AOR}=0.36,95 \% \mathrm{CI}: 0.13,0.95)$ and thinness $(\mathrm{AOR}=0$. $49,95 \%$ CI: 0.30, 0.80). The odds of being thin were lower among children from low income households $(\mathrm{AOR}=0$. 47, 95\% CI: $0.25,0.88)$. Sex was also an important predictor of stunting (Table 4). The odds of being stunted were higher among female children $(\mathrm{AOR}=0.31,95 \% \mathrm{CI}$ : $0.11,0.83)$.

Bivariate analysis of factors associated with vitamin A deficiency (VAD) showed that tapeworm $(\mathrm{COR}=3.89$, 95\% CI: $1.53,9.89)$ and whipworm $(\mathrm{COR}=3.57,95 \% \mathrm{CI}$ : $1.40,9.07)$ increased the risk of having VAD. After simultaneous adjustment for all confounders, multivariate logistic regression analysis showed that the association between tapeworm $(\mathrm{AOR}=3.59,95 \% \mathrm{CI}: 1.06,12.13)$ and whipworm $(\mathrm{AOR}=3.79$; 95\% CI: 1.12, 12.89) with VAD 
Table 2 Anthropometric indices, serum vitamin A and zinc status of the school children

\begin{tabular}{|c|c|c|c|c|c|c|}
\hline & $6-9$ years & $10-12$ years & $13-15$ years & Total & & \\
\hline Variables & N (\%) & N (\%) & N (\%) & N (\%) & *P value & $95 \% \mathrm{Cl}$ \\
\hline \multicolumn{7}{|l|}{ Weight-for-age $(N=176)$} \\
\hline Underweight & $23(15.6)$ & $9(31.1)$ & $\ldots \ldots$ & $32(18.2)$ & \multirow[t]{4}{*}{0.037} & $10.3-27.3$ \\
\hline Normal & 109(74.2) & $20(68.9)$ & …..... & 129(73.3) & & $59.1-87.5$ \\
\hline Overweight & 15(10.2) & $0(0.0)$ & $\ldots \ldots$ & $15(8.5)$ & & $4.5-13.1$ \\
\hline Total & 147(100.0) & 29(100.0) & $\ldots \ldots$ & 176(100.0) & & \\
\hline \multicolumn{7}{|l|}{ Height-for-age $(N=450)$} \\
\hline Stunted & $50(34.0)$ & $52(44.1)$ & $85(45.9)$ & 187(41.6) & \multirow[t]{3}{*}{0.002} & $25.0-45.5$ \\
\hline Normal & $97(65.0)$ & $66(55.9)$ & $100(54.1)$ & $262(58.4)$ & & $47.7-75.6$ \\
\hline Total & 147(100.0) & 118(100.0) & 185(100.0 & $450(100.0)$ & & \\
\hline \multicolumn{7}{|c|}{ Body Mass Index-for-age $(N=450)$} \\
\hline Thinness & 20(13.6) & $17(14.4)$ & $53(28.6)$ & $90(20.0)$ & \multirow[t]{4}{*}{0.000} & $6.8-22.1$ \\
\hline Normal & $94(70.7)$ & $91(77.1)$ & $123(66.5)$ & $318(70.7)$ & & $58.5-88.1$ \\
\hline Overweight & 23(15.7) & $10(8.5)$ & $9(4.9)$ & $42(9.3)$ & & $8.0-18.2$ \\
\hline Total & $147(100.0)$ & $118(100.0)$ & 185(100.0) & $450(100.0)$ & & \\
\hline \multicolumn{7}{|c|}{ Serum vitamin A status $(N=90)$} \\
\hline Deficient $(\leq 20 \mu \mathrm{g} / \mathrm{dl})$ & $18(56.2)$ & $11(44.0)$ & $17(51.5)$ & $46(51.1)$ & \multirow[t]{3}{*}{0.497} & $41.1-61.1$ \\
\hline Normal (> 20 ㅆg/dl) & 14(43.8) & 14(56.0) & $16(48.5)$ & $44(48.9)$ & & $38.9-58.9$ \\
\hline Total & $32(100.0)$ & $25(100.0)$ & $33(100.0)$ & $90(100.0)$ & & \\
\hline \multicolumn{7}{|l|}{ Serum zinc status $(N=90)$} \\
\hline Normal $(\geq 80 \mu \mathrm{g} / \mathrm{dl})$ & $17(53.1)$ & 13(52.0) & $21(63.6)$ & $51(56.7)$ & \multirow[t]{3}{*}{0.595} & $46.7-66.7$ \\
\hline Deficient $(<80$ g/dl) & $15(46.9)$ & $12(48.0)$ & $12(36.4)$ & $39(43.3)$ & & $33.3-53.3$ \\
\hline Total & $32(100.0)$ & $25(100.0)$ & $33(100.0)$ & $90(100.0)$ & & \\
\hline
\end{tabular}

${ }^{*} P$ values were generated through chi square analysis, $\mathrm{Cl}$ Confidence interval

remained significantly $(P<0.05)$ strong (Table 5$)$. The odds of having zinc deficiency was significantly lower among children who were infected with tapeworm (AOR $=3.64,95 \% \mathrm{CI}: 1.02,12.98)(\mathrm{P}<0.05)$ and whipworm $(\mathrm{AOR}=3.80,95 \% \mathrm{CI}: 1.11,13.04) \quad(\mathrm{P}<0.05)$; and those who had males as their household heads $(\mathrm{AOR}=0.23$, 95\% CI: 0.07, 0.69) $(P<0.01)$. The relationship between intakes and under-nutrition was not significant $(P>0.05)$.

\section{Discussion}

Underweight, stunting, thinness, zinc and vitamin A deficiencies were prevalent among the school children. The prevalence of stunting, underweight and thinness reported in this study was higher than the values reported by Nwamara et al. [6] but lower than the report of Atawodi et al. [3]. Vitamin A deficiency prevalence in this study was higher than the findings of Atimati et al. [10] and Egbi [17]. Both reported vitamin A deficiency prevalence of $29.6 \%$ and $35.6 \%$, respectively. Abah et al. [8] reported a much higher prevalence (99.2\%) of zinc deficiency than observed in this study. The consequences of these nutrition problems are often staggering with high morbidity due to lowered immunity and compromised physiology and may be associated with mortality among affected school children. The high morbidity may result to high absenteeism from school as Mahawithanage et al. [18] affirmed that better serum vitamin A status is associated with improved school attendance. We observed that these nutrition problems were associated with multiple factors.

According to this study, the prevalence of underweight, stunting and thinness, vitamin A and zinc deficiencies was lower among children whose household heads were females. This was significant $(P<0.05)$ for underweight and zinc deficiency only. This finding was not a surprise. Culturally, women are better care takers of children than men. Some have been observed to go hungry to ensure that food was enough for their children especially in households that are food insecure. Ene-Obong et al. [19] affirmed that most women gave their children and husbands preference in food distribution. Johnson and Rogers [20] noted that children from female headed households are at least well nourished compared to those living in male headed households of the same income class. This emphasizes the need to empower women to ensure higher socioeconomic power and therefore better 
Table 3 Bivariate analysis of factors associated with underweight, stunting and thinness among the school children

\begin{tabular}{|c|c|c|c|}
\hline \multirow[t]{2}{*}{ Variables } & Weight - for - age & Height - for - age & $\mathrm{BMI}$ - for - age \\
\hline & COR $(95 \% \mathrm{Cl})$ & COR $(95 \% \mathrm{Cl})$ & COR $(95 \% \mathrm{Cl})$ \\
\hline \multicolumn{4}{|l|}{ Characteristics of the school children } \\
\hline Female school children & $1.67(0.76-3.66)$ & $0.68(0.47-0.99)^{*}$ & $1.03(0.65-1.64)$ \\
\hline Older school children (10-15 years) & $2.43(0.98-5.99)^{*}$ & $1.60(1.06-2.41)^{*}$ & $1.91(1.11-3.28)^{*}$ \\
\hline Secondary school children & & $1.07(0.73-1.56)$ & $1.60(1.01-2.55)^{*}$ \\
\hline \multicolumn{4}{|l|}{ Mothers'/Household characteristics } \\
\hline 35 years and above & $0.55(0.25-1.19)$ & $1.00(0.68-1.47)$ & $0.95(0.59-1.54)$ \\
\hline$\geq$ Secondary education & $1.39(0.64-2.99)$ & $1.00(0.67-1.49)$ & $0.70(0.42-1.17)$ \\
\hline Female household head & $0.30(0.13-0.70)^{* *}$ & $0.90(0.62-1.32)$ & $0.60(0.37-0.97)^{*}$ \\
\hline Income above 25,000 Naira (> 79.43\$) & $0.31(0.11-0.85)^{*}$ & $0.61(0.40-0.93)^{*}$ & $0.36(0.19-0.67)^{* *}$ \\
\hline Weekly food expenditure $>5000$ Naira (> 15.89\$) & $0.18(0.08-0.40)^{* * *}$ & $0.55(0.38-0.80)^{* *}$ & $0.40(0.25-0.64)^{* * *}$ \\
\hline \multicolumn{4}{|l|}{ Intakes } \\
\hline Inadequate energy intake & $0.38(0.08-1.82)$ & $1.06(0.43-2.64)$ & $0.66(0.25-1.78)$ \\
\hline Inadequate carbohydrate intake & & $2.03(0.66-6.22)$ & $2.28(0.71-7.29)$ \\
\hline \multicolumn{4}{|l|}{ Micronutrient status } \\
\hline Vitamin A deficiency & $1.53(0.32-7.29)$ & $1.23(0.53-2.88)$ & $1.34(0.52-3.48)$ \\
\hline Zinc deficiency & $3.00(0.63-14.37)$ & $1.42(0.60-3.33)$ & $1.28(0.49-3.31)$ \\
\hline \multicolumn{4}{|l|}{ Parasitic infections } \\
\hline Malaria present & $0.24(0.05-1.16)$ & $0.34(0.14-0.81)^{*}$ & $1.12(0.42-2.94)$ \\
\hline Hookworm present & $0.57(0.10-3.27)$ & $0.69(0.28-1.68)$ & $0.89(0.33-2.41)$ \\
\hline Roundworm present & $2.00(0.38-10.41)$ & $1.34(0.53-3.43)$ & $0.89(0.31-2.60)$ \\
\hline Tapeworm present & $1.88(0.42-8.44)$ & $0.38(0.15-0.99)^{*}$ & $1.23(0.46-3.27)$ \\
\hline Whipworm present & $0.49(0.09-2.81)$ & $0.52-0.21-1.32)$ & $1.69(0.64-4.46)$ \\
\hline Entamoeba hystolitica present & $1.25(0.28-5.59)$ & $0.71(0.30-1.69)$ & $0.39(0.14-1.10)$ \\
\hline
\end{tabular}

COR Crude odds ratio, $C I$ Confidence interval, $B M I$ Body mass index, ${ }^{*} P<0.05{ }^{*} P<0.01{ }^{* * *} P<0.001$

nutritional status of their children. In support of this, Donkoh et al. [21] showed that more female headed households spent greater percentage of their incomes on food than male headed households. Culturally, females become household heads due to physical absence of their spouses as a result of migration, divorce/separation, abandonment and death.

Weekly food expenditure was shown in this study to be an important predictor of underweight, stunting and thinness. Ochieng' [22] and Torlesse et al. [23] reported similar findings. This result was expected because when income is low, the amount of money spent on food will invariably be low implying higher food insecurity in low income households especially when most foods are not in season. Household income has been identified by other authors [24, 25] as a factor causing nutrition problems in children. Most often when income is limited, food and food related expenditures in households are the most compromised. Higher food expenditure may imply increased access to food, higher diversity scores and lower prevalence of undernutrition because improvement in both quality and quantity of food consumed is guaranteed.
Sex was found to be an independent determinant of stunting among the study group. The higher prevalence among males is in agreement with observations by other researchers [26-28]. Kabubo-Mariara et al. [28] reported that boys are more likely than girls to suffer from chronic and acute under-nutrition. Mwaniki and Makokha [29] reported that boys aged 4-7 and 8-11 years had a higher risk of being stunted as compared to girls of the same age. This may be a result of inadequate nutrient intake and higher physical activity levels. Lenhart et al. [30] reported that girls were less likely to be active than boys: $27.9 \%$ of girls were sedentary as compared to $10.6 \%$ of boys. Besides, males have higher basal metabolic rates. These may lead to higher energy expenditure among them and in the face of inadequate intake may lead to higher prevalence of under-nutrition especially stunting, an index of chronic nutrition deprivation.

In this study, we found that tapeworm and whipworm infections were significantly associated with vitamin A and zinc deficiencies. These are endoparasites which depend on their hosts for foods thus depriving the host of essential nutrients. Quihui-Cota et al. [31] reported higher z-scores 
Table 4 Multivariate analysis of risk factors for underweight, stunting and thinness among the school children

\begin{tabular}{|c|c|c|c|}
\hline Independent variables & $\mathrm{AOR}$ & $95 \% \mathrm{Cl}$ & $P$ value \\
\hline & & Underweigh & \\
\hline Female household head & 0.30 & $0.12-0.75$ & $0.010^{*}$ \\
\hline Income above 25,000 Naira (79.43\$) & 0.63 & $0.21-1.92$ & 0.419 \\
\hline Weekly food expenditure above 5000 Naira (15.89\$) & 0.19 & $0.08-0.46$ & $0.000^{* * *}$ \\
\hline Older school children (10-15 years) & 1.57 & $0.56-4.44$ & 0.392 \\
\hline \multirow[t]{2}{*}{ Female school children } & 1.51 & $0.63-3.58$ & 0.354 \\
\hline & \multicolumn{3}{|c|}{ Stunting } \\
\hline Income above 25,000 Naira (79.43\$) & 1.01 & $0.31-3.29$ & 0.986 \\
\hline Weekly food expenditure above 5000 Naira (15.89\$) & 0.36 & $0.13-0.95$ & $0.039^{*}$ \\
\hline Female school children & 0.31 & $0.11-0.83$ & $0.020^{*}$ \\
\hline Older school children (10-15 years) & 1.45 & $0.51-4.16$ & 0.488 \\
\hline Malaria present & 0.37 & $0.12-1.10$ & 0.072 \\
\hline \multirow[t]{2}{*}{ Tapeworm present } & 0.69 & $0.22-2.20$ & 0.530 \\
\hline & \multicolumn{3}{|c|}{ Thinness } \\
\hline Secondary school children & 1.20 & $0.66-2.16$ & 0.550 \\
\hline Income above 25,000 Naira (79.43\$) & 0.47 & $0.25-0.88$ & $0.019^{*}$ \\
\hline Weekly food expenditure above 5000 Naira (15.89\$) & 0.49 & $0.30-0.80$ & $0.005^{* *}$ \\
\hline Older school children (10-15 years) & 1.35 & $0.68-2.69$ & 0.392 \\
\hline Female school children & 0.68 & $0.42-1.12$ & 0.129 \\
\hline
\end{tabular}

AOR Adjusted odds ratio, $C$ C Confidence interval, ${ }^{*} P<0.05{ }^{* *} P<0.01{ }^{* * *} P<0.001$

Table 5 Predictors of vitamin A and zinc deficiencies among the school children

\begin{tabular}{|c|c|c|c|c|}
\hline \multirow[t]{2}{*}{ Variables } & \multicolumn{2}{|l|}{ Serum vitamin A } & \multicolumn{2}{|l|}{ Serum zinc } \\
\hline & $\operatorname{COR}(95 \% \mathrm{Cl})$ & AOR $(95 \% \mathrm{Cl})$ & COR $(95 \% \mathrm{Cl})$ & AOR $(95 \% \mathrm{Cl})$ \\
\hline \multicolumn{5}{|l|}{ Characteristics of the school children } \\
\hline Female school children & $1.70(0.74-3.94)$ & $1.47(0.55-3.94)$ & $1.15(0.50-2.66)$ & $1.15(0.42-3.17)$ \\
\hline Older school children (10-15 years) & $0.73(0.31-1.73)$ & $1.15(0.37-3.57)$ & $0.80(0.34-1.91)$ & $1.38(0.44-4.36)$ \\
\hline \multicolumn{5}{|l|}{ Mothers'/Household characteristics } \\
\hline 35 years and above & $0.51(0.22-1.20)$ & $0.45(0.16-1.29)$ & $0.43(0.18-1.03)$ & $0.35(0.12-1.07)$ \\
\hline$\geq$ Secondary education & $1.14(0.48-2.75)$ & $0.79(0.27-2.37)$ & $1.00(0.41-2.42)$ & $0.49(0.15-1.63)$ \\
\hline Female household head & $1.83(0.77-4.38)$ & $1.43(0.51-4.01)$ & $2.38(0.96-5.89)$ & $0.23(0.07-0.69)^{* *}$ \\
\hline Income > 25,000 Naira (79.43\$) & $1.70(0.65-4.47)$ & 2.97(0.79-11.16) & $1.01(0.39-2.62)$ & $2.28(0.62-8.37)$ \\
\hline WFE > 5000 Naira (15.89\$) & $0.99(0.44-2.28)$ & $0.93(0.35-2.49)$ & $1.12(0.49-2.59)$ & $1.09(0.41-2.94)$ \\
\hline \multicolumn{5}{|l|}{ Nutrient intake } \\
\hline Inadequate vitamin A intake & $0.94(0.37-2.39)$ & $0.72(0.21-2.48)$ & & \\
\hline \multicolumn{5}{|l|}{ Parasitic infections } \\
\hline Malaria present & $1.71(0.73-3.99)$ & $0.36(0.09-1.44)$ & $2.16(0.90-5.18)$ & $0.65(0.17-2.56)$ \\
\hline Hookworm present & $1.51(0.64-3.58)$ & $1.06(0.35-3.24)$ & $1.15(0.48-2.72)$ & $0.58(0.18-1.88)$ \\
\hline Round worm present & $1.05(0.42(2.64)$ & $0.94(0.29-2.99)$ & $1.63(0.64-4.11)$ & $2.40(0.71-8.12)$ \\
\hline Tapeworm present & 3.89 (1.53-9.89) & $3.59(1.06-12.13)^{*}$ & $3.42(1.39-8.43)$ & $3.64(1.02-12.98)^{*}$ \\
\hline Whipworm present & $3.57(1.40-9.07)$ & $3.79(1.12-12.89)^{*}$ & $3.83(1.53-9.57)$ & $3.80(1.11-13.04)^{*}$ \\
\hline Entamoeba hystolitica present & $1.11(0.48-2.57)$ & $1.07(0.37-3.06)$ & $1.93(0.82-4.52)$ & $1.01(0.34-3.02)$ \\
\hline
\end{tabular}


for weight-for-height, weight-for-age, and height-for-age among school children uninfected with intestinal helminths and showed that higher prevalence of intestinal infections in children was associated with lower height-for-age and weight-for-age z-scores. Negative relationship between helminths and nutrition status of children has also been reported by other authors [32-34].

Zinc concentration was also reported to be lower in children with soil transmitted helminths [35]. We opined that both tapeworm and whipworm may have had heavier intestinal load than other intestinal parasites. It probably could also be that these two helminths had longer infective periods than other parasites. Wolde et al. [12] showed a significant relationship between trichuris and stunting; but not with underweight and wasting and asserted that this was a result of chronic nature of trichuris infection. We found no significant association with underweight, stunting and thinness.

Though not significant, we observed that the prevalence of underweight, stunting and thinness was higher among children who had inadequate energy intake. Mwaniki and Makokha [29] reported similar findings. They reported that children who had adequate energy intake were less likely to be underweight than those who had inadequate energy intake. We observed that nutrient intakes were based mainly on plant foods which have low bioavailability. This may be responsible for the lack of significant association between nutrient intake and nutrition status despite intake that exceeded $100 \%$ of the recommended intakes. Though zinc intake was adequate for all the children, we observed zinc deficiency of severe public health importance implying that intake was not reflected on serum zinc status of the children. This calls for bioavailability assessment of our commonly consumed foods.

\section{Limitation of the study}

The study was conducted in a rural community. Though large with ten schools, it is not a true representation of the entire rural areas in Nigeria. However, it has affirmed that nutrition problems among rural school children are public health problems that require a focused multisectoral school- and community-based approaches for their control.

\section{Conclusion}

Among school children in Ede-Oballa, underweight, stunting, thinness, vitamin $\mathrm{A}$ and zinc deficiencies were nutrition problems of public health significance. Weekly food expenditure was an independent predictor of underweight, stunting and thinness. Gender of household head was also a predictor of underweight. Sex was an independent predictor of stunting and household income was significantly associated with thinness. Gender of household head, whipworm and tapeworm were major factors contributing to zinc deficiency. Tapeworm and whipworm were also important determinants of vitamin A deficiency. Empowerment of females through free education for the girl-child, and loans to adult females is necessary to ensure sustained better nutritional status of children. A functional school health and feeding programme is vital to improve nutrient intake and enhance deworming and vitamin A supplementation among school children to boost their immunity and ensure better nutritional and health status.

\section{Acknowledgements \\ The authors are grateful to the school children and their parents for their wonderful cooperation during data collection and especially during the 3-day weighed food intake. We also appreciate late Professor Elizabeth C. Okeke who was involved in the design of this study. She died before the study was concluded.}

\section{Funding}

The authors declare that they did not receive any funding whatsoever for the study, authorship and publication.

\section{Availability of data and materials}

All data generated and analysed in the course of this study are not publicly available to maintain confidentiality of individual responses. The datasets of this study are available from the corresponding author on reasonable request.

\section{Authors' contributions}

RNB conceived and designed the study; acquired, analysed and interpreted the data, and drafted the manuscript. IC, EU and EA participated in interpretation of the data, drafting and revising the manuscript. All authors read and approved the final manuscript.

\section{Ethics approval and consent to participate}

Ethical clearance for this study was obtained from the ethical committee of the Enugu State Ministry of Health (MH/MSD/38). Details of the study were explained to the school children and their parents. The parents gave written consent for their children to participate in the study. The children also gave oral consent confirming their willingness to participate in the study.

\section{Competing interests}

The authors declared that they have no competing interests.

\section{Publisher's Note}

Springer Nature remains neutral with regard to jurisdictional claims in published maps and institutional affiliations.

Received: 7 February 2017 Accepted: 19 April 2018

Published online: 02 May 2018

\section{References}

1. Miller DD, Welch RM. Food system strategies for preventing micronutrient malnutrition. ESA working paper no. 13-06. Rome: Agricultural Development Economics Division, FAO; 2013. http://www.fao.org/fileadmin/ templates/esa/Papers_and_documents/WP_13_06 Accessed 10 June 2014.

2. Oninla SO, Owa JA, Onayade AA, Taiwo O. Comparative study of nutritional status of urban and rural Nigerian school children. J Trop Paed. 2007:53:39-43.

3. Atawodi SE, Aliyu B, Abbasi O, Ilouno LE. Nutritional status of primary schoolchildren in Kawo district of Kaduna metropolis, Nigeria. Ann Res Rev Biol. 2015;5(1):64-70.

4. Olanrele DI. Assessment of nutritional status of schoolchildren in Oyo west local government area, Oyo state, Nigeria. Nig J Nutr Sci. 2014;35(2):99-104.

5. Onabanjo OO, Balogun OL (2014). Anthropometric and iron status of adolescents from 401 selected secondary schools in Ogun state, Nigeria. Childhood Obesity Nutr. 2014;6(2):402 109-118. https://doi.org/10.1177/ 1941406414520703. Accessed 31 Jan 2016. 
6. Nwamara JU, Otitoju O, Otitoju GTO, Emewulu CUD. lodine and nutritional status of primary school children in a Nigerian community, Okpuje, in Nsukka LGA, Enugu state, Nigeria. Pharm Lett. 2015;7(7):271-8.

7. Akeredolu IA, Oguntona BE, Okafor C, Osisanya OJ. Iron, zinc and copper malnutrition among primary school children in Lagos, Nigeria. Food Nutr Sci. 2011:2:1063-70. https:/doi.org/10.4236/fns.210142. Accessed 5 July 2015.

8. Abah RO, Okolo SN, John C, Ochoga MO. Prevalence of zinc deficiency among school children in a rural setting in north-Central Nigeria. Int J Pub Health Res. 2015;3(5):214-7.

9. Chukwuka JO, Chukwuka UB. The prevalence of anaemia in rural primary school children in Ekwusigo local government area, Anambra state, Nigeria. Orient J Med. 2014;26(3-4):122-7.

10. Atimati $\mathrm{AO}$, Abiodun $\mathrm{PO}$, Ofovwe GE. High prevalence of vitamin a deficiency in school age children in Benin City. Ann Biomed Sci. 2012; 11(1):106-16.

11. Ene-Obong HN, Odoh IF, Ikwuagwu OE. Plasma vitamin a and C status of in-school adolescents and associated factors in Enugu state, Nigeria. J Health Popul Nutr. 2003;21:18-25.

12. Wolde M, Berhan Y, Chala A. Determinants of underweight, stunting and wasting among school children. BMC Pub Health. 2015;15:8. https://doi.org/ 10.1186/s12889-014-1337-2

13. Grantham-McGregor SM, Ani CC. Undernutrition and mental development. In: Fernstrom JD, Uauy R, Arroyo P, editors. Nutrition and brain. Nestle Nutr workshop Ser Clin perform Prog vol 5. Vevey: Nestec Ltd; 2000. p. 1-14. https://www.karger.com/Article/Abstract/61844. Accessed 2 Feb 2017.

14. World Health Organization. WHO growth standards for children 5-19 years. 2007. http://www.who.int/childgrowth/standards/en/. Accessed 4 Oct 2015.

15. Papier J, Williams GM, Luceres-Catubig R, Ahmed F, Olveda RM, McManus DP, Chy D, Chau TN, Gray DJ, Ross AG. Childhood malnutrition and parasitic helminth interactions. Clin Infect Dis. 2004;59:234-43.

16. Oguntona T, Omojekun SO, Aminu FT, Demehin KO, Falana AO. Federal Ministry of Health national guidelines on micronutrient deficiencies control in Nigeria. Abuja: Department of Community Development and Population Activities (Nutrition division); 2005. p. 15-29.

17. Egbi G. Prevalence of vitamin a, zinc, iodine deficiency and anaemia among 2-10 year- old Ghanaian children. Afr J Food Agric Nutr Dev. 2012;12:5946-58.

18. Mahawithanage STC, Kannangara KKNP, Wickremasinghe R, Chandrika UG, Jansz ER, Karunaweera ND, Wickremasinghe AR. Impact of vitamin a supplementation on health status and absenteeism of school children in Sri Lanka. Asia Pac J Clin Nutr. 2007;16(1):94-102.

19. Ene-Obong HN, Enugu GI, Uwaegbute AC. Determinants of health and nutritional status of rural Nigerian women. J Health Popul Nutr. 2001;19:320-30

20. Johnson FC, Rogers BL. Children's nutritional status in female headed households in the Dominican Republic. Soc Sci Med. 1993;37:1292-301.

21. Donkoh SA, Alhassan H, Nkegbe PK. Food expenditure and household welfare in Ghana. Afr J Food Sci. 2014;8:164-75.

22. Ochieng' CS. Effects of household food expenditure on child nutritional status in Kenya. Social sector division, Kenya Institute for Public Policy Research and analysis (KIPPRA) discussion paper no. 156. 2013.

23. Torlesse H, Kiess L, Bloem MW. Association of household rice expenditure with child nutritional status indicates a role for macroeconomic food policy in combating malnutrition. J Nutr. 2003;133:1320-5.

24. Osei A, Houser R, Bulusu S, Joshi T, Hamer D. Nutritional status of primary school children in Garhwali Himalayan villages of India. Food Nutr Bull. 2010;31:221-33

25. Engle PL. Influences of mothers' and fathers' income on children's nutritional status in Guatemala. Soc Sci Med. 1993:37:1303-12.

26. Wmana H, Astrom AN, Peterson S, Tumwine JK, Tylleskar T. Boys are more stunted than girls in sub-Saharan Africa: a meta-analysis of 16 demographic and health surveys. BMC Paed. 2007;7:17. https://doi.org/ 10.1186/1471-2431-7-17

27. Fetuga B, Ogunlesi TA, Adekanmbi AF, Alabi AD. Nutritional status of semiurban Nigerian school children using the 2007 WHO reference population. West Afr J Med. 2011;30(5):331-6.

28. Kabubo-Mariara J, Ndenge GK, Mwabu DK. Determinants of children's nutritional status in Kenya: evidence from demographic and health surveys. J Afr Econ. 2008;18:363-87.
29. Mwaniki EW, Makokha AN. Nutrition status and associated factors among children in public primary schools in Dagoretti, Nairobi, Kenya. Afr Health Sc. 2013;13:39-46. https://doi.org/10.4314/ahs.v13i1.6.

30. Lenhart CM, Hanlon A, Kang Y. Gender disparity in structured physical activity and overall activity level in adolescence: evaluation of youth risk behaviour surveillance data. Int Sch Res Network Pub Health. 2012;8. https://doi.org/10.5402/2012/674936. Accessed 2 June 2015.

31. Quihui-Cota L, Valencia ME, Crompton DWT, Phillips S, Hagan P, DiazCamacho SP, et al. Prevalence and intensity of intestinal parasitic infections in relation to nutritional status in Mexico school children. Trans Royal Soc Trop Med Hyg. 2004;98(11):653-9.

32. Osazuwa F, Ayo OM, Imade P. A significant association between intestinal helminth infection and anaemia burden in children in rural communities of Edo state, Nigeria. N Am J Med Sci. 2011;3:30-4. https://doi.org/10.4297/najms.2011.330.

33. de Gier B, Campos PM, van de Bor M, Doak CM, Polman K. Helminth infections and micronutrients in school-children: a systematic review and meta-analysis. Am J Clin Nutr. 2014;99:1499-509.

34. Suchdev PS, Davis SM, Bartoces M, Ruth LJ, Worrell CM, Kanyi H, et al. Soil-transmitted helminth infection and nutritional status among urban slum children in Kenya. Am J Trop Med Hyg. 2014;90:299-305. https:// doi.org/10.4269/ajtmh.13-0560.

35. de Gier B, Mpabanzi L, Vereecken K, van der Werff SD, D'Haese PC, Fiorentino $\mathrm{M}$, et al. Height, zinc and soil transmitted helminth infections in schoolchildren: a study in Cuba and Cambodia. Nutrients. 2015;7(4):3000-10.

\section{Ready to submit your research? Choose BMC and benefit from:}

- fast, convenient online submission

- thorough peer review by experienced researchers in your field

- rapid publication on acceptance

- support for research data, including large and complex data types

- gold Open Access which fosters wider collaboration and increased citations

- maximum visibility for your research: over $100 \mathrm{M}$ website views per year

At BMC, research is always in progress.

Learn more biomedcentral.com/submissions 